\title{
Nutritional components and oxidative stability of plant seed oils
}

\author{
Jookyeong Lee ${ }^{1 *}$, Seong Jun Hong ${ }^{1 *}$, Joon Hyung Park², Jin-Ju Cho ${ }^{1}$, Da-Som Kim ${ }^{1}$ Kyoung-Tae Lee ${ }^{2}$, \\ Oh-Kyu Lee ${ }^{2}$ and Eui-Cheol Shin ${ }^{1 *}$
}

${ }^{1}$ Department of Food Science, Gyeongnam National University of Science and Technology, Jinju 52725, Republic of Korea, ${ }^{2}$ Forest Biomaterials Research Center, National Institute of Forest Science, Jinju 52725, Republic of Korea

${ }^{*}$ These authors (J. Lee and S-J. Hong) contributed equally to this work.

\section{A B S T R A C T}

\begin{abstract}
This study investigated fatty acid compositions, antioxidative nutrients, physicochemical properties, and oxidative stability of 10 plant seed oils derived from forest resources. Eight types of fatty acids were identified in total, of which oleic acid marked the highest proportion in most of the seed oils. Overall, the seed oils showed relatively higher contents of unsaturated fatty acids $(\geqq 50 \%)$. Tocopherol and phytosterol contents ranged from $4.82 \pm 0.11 \mathrm{mg} / 100 \mathrm{~g}$ to $738.35 \pm 4.30 \mathrm{mg} / 100 \mathrm{~g}$ and from $133.44 \pm 5.09 \mathrm{mg} / 100 \mathrm{~g}$ to $403.59 \pm 29.89 \mathrm{mg} / 100 \mathrm{~g}$, respectively. In terms of chemical measures, acid value, peroxide value, and $p$-anisidine value resulted in broad ranges, between $0.81 \pm 0.04 \mathrm{mg} \mathrm{KOH} / \mathrm{g}$ and $52.3 \pm 0.60 \mathrm{mg} \mathrm{KOH} / \mathrm{g}, 4.95 \pm 0.11 \mathrm{meq} / \mathrm{kg}$ and $213.88 \pm 6.97 \mathrm{meq} / \mathrm{kg}$, and $3.53 \pm 0.39$ and $62.59 \pm 1.67$, respectively. Browning intensity and color scale were also examined, which probably will be a good indicator of sensory quality. As a measure of oxidative stability, oxidation induction period was investigated, showing a range of $0.02 \pm 0.01 \mathrm{hr}$ to $3.72 \pm 0.28 \mathrm{hr}$. This study provided informative fundamental data on forest resource derived- 10 plant seed oils and demonstrated the possibility of these oils as edible oil sources with favorable nutrient and physicochemical features.
\end{abstract}

Keywords: Fatty acids; Oxidative stability; Phytosterols; Plant seed oils; Tocopherols

\section{INTRODUCTION}

Consumption of fats and oils is unavoidable in our diet nowadays. From a nutritional perspective, plant-based oils are superior to animal-based oils and products. Particularly, plant- based oils are composed of high amounts of unsaturated fatty acids such as linoleic and linolenic acids, which deliver many physiological and nutritional benefits to human body (Bowen et al., 2019). Literature highlighted that conjugated linoleic acids (CLA), a group of linoleic acid isomers, are effective in the prevention of obesity, atherosclerosis, and cancer (Nakamura et al., 2008; Lee et al., 2005). Alpha-linolenic acids, known as an omega-3 fatty acid, provide many biological roles in human body including anti-inflammatory and anti-cancer effects (Marventano et al., 2015; Innes and Calder, 2018) and act as precursors of long chain polyunsaturated fatty acids, docosahexaenoic aicd (DHA), docosapetaenoic acid (DPA), and eicosapentaenoic acid (EPA) (Burge and Wootton, 2002). Additionally, plant-based oils contain high amounts of tocopherols and phytosterols, which enhance food storability as well as nutritional quality (Kim et al., 2018).

As described, recent literature on plant-based oils indeed rely on bioactivities and physiological efficacies. Additionally, whereas many studies have been investigated plant-based oils, they mainly focused on commercially available oil products such as olive, soybean, canola, sunflower, and rapeseed oils, and investigated genetic engineering, microorganism induced modification, and toxicity (Wayne et al., 2018; Khan et al., 2019). Only a few studies have been demonstrated plant seed oils from wild forest resources. Kim et al. (2017) analyzed lipid characteristics and physicochemical properties of plant oils from Garae, Dongback, Mongwi, and Muwhanja. Kim et al. (2018) also reported fatty acid profiles and chemical properties of six plant sourced oils and classified them based on the length of fatty acid chains. Kim and colleagues demonstrated chemical characteristics of wasabi extracted oils and alterations encountered during frying process (Kim

\footnotetext{
${ }^{*}$ Corresponding author:

Eui-Cheol Shin, Department of Food Science, Gyeongnam National University of Science and Technology, Jinju 52725, Republic of Korea.

Phone: +82-55-751-3271. E-mail: eshin@gntech.ac.kr
} 
et al., 2018). There are a myriad plant seed oils originated from forests and they possibly become an excellent edible oil source. Recent studies, however, have rarely looked for their potential as a food source and food ingredient. In an effort to explore the capacity of oils from forests, establishing baseline information including fatty acid profiles and physicochemical properties that may have impacts on sensory acceptability and food processing and storage is a matter of paramount importance.

Therefore, this study aimed to investigate fatty acid composition, fat-soluble nutrient contents (tocopherol and phytosterol), chemical measures associated with oxidative stability (acid value, peroxide value, and $p$-anisidine value), browning intensity and color scale, and oxidation-induction period in 10 plant seed oils obtained from forest resources; camphor tree (Camphora officinarum T.), Australian laurel (Delastrus tobira T.), Chinese flowering-quince (Chaenomeles chinensis K.), fragrant citrus (Citrus junos Siebold ex T.), Japanese mallotus (Mallotus japonicus M.), tea camellia (Camellia sinensis L.), deodar (Cedrus deodara G.), nakedanther ternstroemia (Ternstroemia gymnanthera S.), Korean red pine (Pinus densiflora S.), and large-leaflet prickly-ash (Zanthoxylum coreanum N.). These plant samples are widely grown in Asian countries including Korea but only few studies have explored their nutritional constituents and physicochemical properties. As an extension of previous studies by our research team (Kim et al., 2017; Kim et al., 2018), this study will be a foundation in utilization and application of forest oils as food sources.

\section{MATERIALS AND METHODS}

\section{Materials}

The plant seeds were harvested and collected by Forest Biomaterials Research Center, Jinju, Republic of Korea, in 2017. The oils were extracted using 10X $n$-hexane of sample weights at $4^{\circ} \mathrm{C}$ for $12 \mathrm{hr}$ while stirring. The extracted samples were then treated with stream of nitrogen and stored at $-20^{\circ} \mathrm{C}$ until further analyses. Voucher numbers of 10 samples are GFC21 to GFC30. All chemicals and standards used in this study were purchased from SigmaAldrich Co.(St. Louis, MO, USA). HPLC grade was used for hexane, methanol $\left(\mathrm{CH}_{3} \mathrm{OH}\right)$, and ethanol and ACS grade for anhydrous sodium sulfate $\left(\mathrm{Na}_{2} \mathrm{SO}_{4}\right)$, isooctane, and diethyl ether.

\section{Fatty acid composition}

To investigate fatty acid composition, boron trifluoride $\left(\mathrm{BF}_{3}\right)$ methanol was used to derivatize to fatty acid methyl ester(FAME) (Prato and Biandolino, 2012). The sample $(100 \mathrm{mg})$ was placed in a test tube and then $0.5 \mathrm{~mL}$ of heptadecanoic $\operatorname{acid}(\mathrm{C} 17: 0)(1 \mathrm{mg} / \mathrm{mL}$ hexane $)$ was added as an internal standard. Next, $0.2 \mathrm{~mL}$ of $0.5 \mathrm{~N}$ $\mathrm{NaOH}$-methanol was added to the test tube and subjected to heat treatment at $110^{\circ} \mathrm{C}$ for $10 \mathrm{~min}$ using Reacti-Therm III Heating/Stirring Module (Thermo Fisher Scientific Co., Rockford, IL, USA). After cooling at room temperature for $20 \mathrm{~min}, 4 \mathrm{~mL}$ of $\mathrm{BF}_{3}$-methanol was added to the test tube and heated at $110^{\circ} \mathrm{C}$ for $1 \mathrm{hr}$ for derivatization. $2 \mathrm{~mL}$ of hexane was added to the cooled sample and mixed for 1 min, after which the hexane layer was collected. Fatty acids were analyzed by gas chromatography using Agilent Technologies 6890N (Agilent Technologies, Santa Clara, CA, USA). SP-2560 capillary column $(100 \mathrm{~m} \times 0.25 \mathrm{~mm}$ i.d., $0.25-\mu \mathrm{m}$ film thickness; Agilent Technologies) was used as a column and nitrogen $(2.7 \mathrm{~mL} / \mathrm{min})$ was used as a carrier gas. Temperature of both inlet and the detector was set to $250^{\circ} \mathrm{C}$ and the split ratio of inlet was $10: 1$. The temperature for oven was initially programmed at $130^{\circ} \mathrm{C}$ for $5 \mathrm{~min}$, increased to $240^{\circ} \mathrm{C}$ by $4^{\circ} \mathrm{C} / \mathrm{min}$, and maintained for $15 \mathrm{~min}$. The results were analyzed by the retention time of 37 types of fatty acid standards (Supelco 37 FAME, Sigma-Aldrich Co., St. Louis, MO, USA).

\section{Vitamin E (tocopherols) content}

To measure tocopherol content of the plant seed oils, the sample $(1 \mathrm{~g})$ was dissolved in $50 \mathrm{~mL}$ of hexane and homogenized. The mixture was filtered using a 0.45 $\mu \mathrm{m}$ nylon membrane filter (GE Osmonics Labstore, Minnetonka, MN, USA). Tocopherol content was estimated by Normal-HPLC system (Agilent 1260, Agilent Technologies) mounted with a fluorescence detector. Column used in the analysis was a normal phase LiChrosorb Si-60 column $(4 \mathrm{~mm} \times 250 \mathrm{~mm}, 5 \mu \mathrm{m}$ particle size; Hibar ${ }^{\circledR}$ Fertigsäule RT, Merck, Darmstadt, Germany). $0.85 \%$ isopropanol/hexane was used as mobile phase and flow rate was set to $1.0 \mathrm{~mL} / \mathrm{min}$. Excitation and emission wavelength for the detector was set to $290 \mathrm{~nm}$ and $330 \mathrm{~nm}$, respectively. $\alpha$-, $\beta$-, $\gamma$-, and $\delta$-tocopherols were quantified by comparing the retention times of reference standards (Kim et al., 2017).

\section{Phytosterol content}

Alkaline saponification method was used for analyzing phytosterols present in the plant seed oils (Shin et al., 2010). The sample, $500 \mathrm{mg}$, was placed in a test tube and $0.5 \mathrm{~mL}$ of $5 \alpha$-cholestane $(1 \mathrm{mg} / \mathrm{mL}$ hexane) was added as an internal standard. Then, $3 \%(\mathrm{w} / \mathrm{v})$ pyrogallol-ethanol $(8 \mathrm{~mL})$ and saturated $\mathrm{KOH}$ solution $(1 \mathrm{~mL})$ were added to the test tube and heated at $80^{\circ} \mathrm{C}$ for $1 \mathrm{hr}$, followed by extraction using hexane. After derivatization using BSTFA (N,Obis(trimethylsilyl)trifluoroacetamide+trimethylchlorosila ne), phytosterols were analyzed using a gas chromatography (GC) installed with a flame ionization detector (FID). The column used in the analysis was HP-5 $(30 \mathrm{~m} \times 0.32 \mathrm{~mm}$ i.d., $0.25 \mu \mathrm{m}$ film thickness; Agilent Co., USA) and nitrogen 
$(2.7 \mathrm{~mL} / \mathrm{min})$ was used as a carrier gas. The oven was initially set to $260^{\circ} \mathrm{C}$, increased to $300^{\circ} \mathrm{C}$ by $3^{\circ} \mathrm{C} / \mathrm{min}$, and maintained for $15 \mathrm{~min}$. The inlet and detector temperatures were set to $300^{\circ} \mathrm{C}$ and $320^{\circ} \mathrm{C}$, respectively. Identification and quantification of phytosterols were performed by retention time and peak areas using reference standards.

Acid value, peroxide value, and $\boldsymbol{p}$-anisidine value

Acid value of plant seed oils was estimated by AOCS method (1990a). The sample (1 g) was dissolved in $30 \mathrm{~mL}$ of solution mixed with ethanol: ether in $1: 1(\mathrm{v} / \mathrm{v})$. Then, $1 \%$ phenolphthalein solution, $100 \mu \mathrm{L}$, was added as an indicator and the mixture was titrated by $0.1 \mathrm{~N}$ potassium hydroxide $(\mathrm{KOH}) /$ ethanol solution until the mixture turned to light red.

Peroxide value was determined by AOCS method (1990b). The sample $(5 \mathrm{~g})$ was dissolved in $25 \mathrm{~mL}$ of solution mixed with acetic acid: chloroform in $3: 2(\mathrm{v} / \mathrm{v}) .1 \mathrm{~mL}$ of $\mathrm{KI}$ solution was added and left in a dark room. After adding $1 \mathrm{~mL}$ of $1 \%$ starch solution, the solution was then titrated by $0.01 \mathrm{~N}$ sodium thiosulfate $\left(\mathrm{Na}_{2} \mathrm{~S}_{2} \mathrm{O}_{3}\right)$ solution until it turned to colorless.

For determination of $p$-anisidine value, the sample (100 mg) was dissolved in $25 \mathrm{~mL}$ of isooctane and the absorbance was measured at $350 \mathrm{~nm} .2 .5 \mathrm{~mL}$ of the solution was taken and mixed with $0.5 \mathrm{~mL}$ of $0.25 \%$ (w/v) para-anisidine/ acetic acid. After reaction for $15 \mathrm{~min}$, the absorbance was measured again at $350 \mathrm{~nm}$ and the absorbance before and after the reaction with anisidine solution was measured to determine $p$-anisidine values (AOCS 1990c).

\section{Color scale and browning intensity}

Color scale of plant seed oils was analyzed using a color difference meter (CR-300, Konica Minolta Inc., Tokyo, Japan). L* (0/100 darkness/lightness), a* (+/-, redness/ greenness), and $\mathrm{b}^{*}(+/-$, yellowness/blueness) values expressed in Hunter scale were measured. Reference values were $L^{*}=92.14, a^{*}=2.54$, and $b^{*}=1.57$. Browning intensity was determined by measuring absorbance at $420 \mathrm{~nm}$ using a spectrophotometer (Multiskan Go, Thermo-Fisher Scientific Co., Vantaa, Finland) (Kim et al., 2017).

\section{Oxidation induction period}

To estimate oxidation induction period of plant seed oils as an index of oxidative stability, rancimat (892 Professional Rancimat, Metrohm AG, Herisau, Switzerland) instrument was used. The sample $(3 \mathrm{~g})$ was placed in a rancimat tube, and after air injection at $20 \mathrm{~L} / \mathrm{hr}$, the system was run at $120^{\circ} \mathrm{C}$. Subsequently, oxygen induction period was determined using the conductivity of sensors that measure oxidation products generated by oxidation (Kim et al., 2017).

\section{Statistical analysis}

All experiments were performed in triplicates and the data were expressed as mean \pm standard deviation. Tukey's multiple range test was used to compare the means by utilizing SAS 9.2 (Statistical Analysis System, Version 9.0, SAS Institute Inc., Cary, NC, USA). $P$-value less than 0.05 was determined to be statistically significant $(P<0.05)$.

\section{RESULTS AND DISCUSSION}

\section{Fatty acid composition}

Fatty acid composition obtained from 10 plant seed oils is described in Table 1 . A total of 8 fatty acids were identified. Of them, there included 4 saturated fatty acids, 2 monounsaturated fatty acids, and 2 polyunsaturated fatty acids. Notably, oleic acid accounted for high proportions throughout the all plant seed oils ranged between $69.34 \pm 0.02 \%$ and $17.02 \pm 2.61 \%$, excepting Chinese flowering-quince and Korean red pine. Oleic acid, rich in olive oils and nuts, is an important monounsaturated fatty that is known to alleviate the risk factors of cardiovascular diseases such as hypertension, overweight and obesity, hyperglycemia, and insulin regulation (Grando-Casas and Mauricio, 2019). Linoleic acid exhibited relatively high levels in Fragrant citrus, Deodar, Naked-anther ternstroemia, and Korean red pine with $48.48 \pm 0.01 \%, 30.99 \pm 0.01 \%$, $30.66 \pm 2.47 \%$, and $48.01 \pm 0.10 \%$, respectively. Linoleic acid is an omega- 6 essential polyunsaturated fatty acid and abundant in plant seeds. Similar to the other essential fatty acids, linoleic acid cannot be produced within human body and is therefore insufficiently present in the body (Noh and Yoon, 2012; Kim et al., 2017). Linoleic acid plays vital biological roles including anti-inflammation (Innes and Calder, 2018), anti-metastasis, anti-cancer cell proliferation, anti-cancer cell apoptosis (Currie et al., 2013; Marventano et al., 2015), anti-angiogenesis, and cardiovascular prevention (Jump et al., 2012; Marventano et al., 2015). Linolenic acid showed relatively higher contents in Australian laurel and Korean red pine with $19.37 \pm 0.03 \%$ and $16.75 \pm 0.01 \%$, respectively, and the rest 8 samples were ranged from $9.45 \pm 0.01 \%$ to $0.01 \pm 0.00 \%$. Linolenic acid, an omega-3 fatty acid, is plentiful in plant seeds, nuts, and plant-derived oils. Linolenic acid regulates metabolic processes in the body and aids cell protection, maintenance, and apoptosis (Burdge, 2004; Nelson, 1992). It further lowers serum cholesterol levels, resists against inflammation, and improves the risk factors of cardiovascular diseases and type II diabetes (Lenighan et al., 2019). Whereas the plant seed oils showed various fatty acid profiles, the samples contained relatively higher amounts of unsaturated fatty acids ( $\geqq 50 \%)$. Fatty acids with high degree of unsaturation have ambilateral aspects. As aforementioned, unsaturated fatty acids provide 


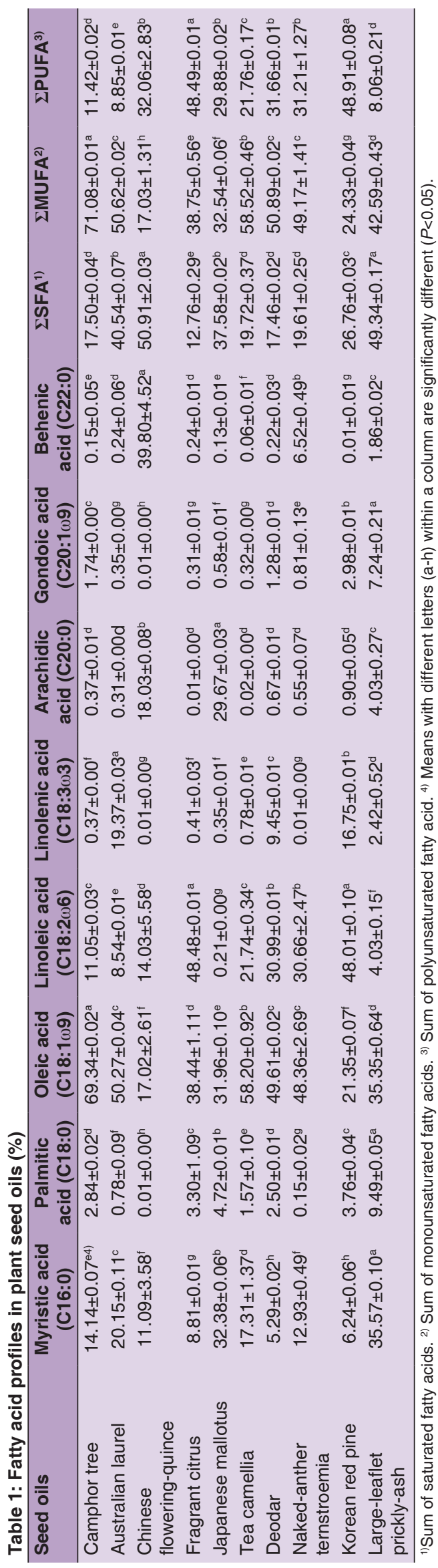

various nutritional and physiological advantages. Such high unsaturation, however, may increase the likelihood of acidification and jeopardize oxidative stability, unfavorably affecting on overall sensory quality and acceptability. Therefore, more investigations are deemed necessary to adequately control acidification and oxidative stability in order to extend the usability of the plant seed oils as food sources and food ingredients.

\section{Tocopherol contents}

Tocopherol contents in 10 plant seed oils are shown in Table 2. Tocopherol contents of the plant seed oils greatly varied, ranging between $4.82 \pm 0.11 \mathrm{mg} / 100 \mathrm{~g}$ and $738.35 \pm 4.30 \mathrm{mg} / 100 \mathrm{~g}$, among which Australian laurel had the highest level of tocopherol while Large-leaflet prickly-ash had the lowest level. Tocopherol is a fat-soluble antioxidant and ubiquitous in vegetable oils, seeds, and nuts (Eitenmiller and Lee, 2004), and when deficient, it may cause autoimmune diseases, diabetes, and neurological damages in an indirect manner (Ghosh et al., 2019). The increased level of tocopherols in human body plays pivotal roles in lowering the risk of developing cardiovascular diseases (Pham and Plakogiannis, 2005), Alzheimer's diseases (Cervantes and Ulatowski, 2017), and cancers (Aggarwal et al., 2019). Tocopherol is comprised of 4 vitamers, namely $\alpha-, \beta-, \gamma^{-}$, and $\delta$ - tocopherols, based on the number and position of methyl group on the chromanol ring (Eitenmiller and Lee, 2004; Shin et al., 2009). In the present study, $\alpha$-tocopherol was most abundant, followed by $\gamma$-, $\beta$-, and $\delta$ - tocopherols. Among 10 plant seed oils, Australian laurel marked the highest level of both $\alpha$-and $\beta$-tocopherols, $473.65 \pm 0.20 \mathrm{mg} / 100 \mathrm{~g}$ and $95.77 \pm 0.05 \mathrm{mg} / 100 \mathrm{~g}$, respectively. $\alpha$ - tocopherol is most biologically active out of 4 types and is directly related to the dietary assessment of vitamin E consumption (Shin et al., 2009) while $\beta$-tocopherol is known to exist minimum in plant-based oils (Kim et al., 2018). In case of $\gamma$-tocopherol, Japanese mallotus contained the highest amount $(295.36 \pm 0.44 \mathrm{mg} / 100 \mathrm{~g})$ and Australian laurel contained the second highest, which is a relatively higher amount $(156.30 \pm 3.51 \mathrm{mg} / 100 \mathrm{~g})$ compared to the rest 8 seed oils. $\gamma$-tocopherol limits the pro-inflammatory cytokine release in the body and is therefore resistant against inflammatory responses (Sozen et al., 2019). Similar to $\beta$-tocopherol, $\delta$ - tocopherol is reported to exist trivial in plants (Kim et al., 2018) and the result of present study also reflects this, showing the highest content in Australian laurel, $12.62 \pm 0.54 \mathrm{mg} / 100 \mathrm{~g}$. Based on the result of this study, Australian laurel showed a relatively higher amount of 4 types tocopherols as well as total tocopherol compared to the other oils.

\section{Phytosterol contents}

Phytosterol contents obtained from 10 plant seed oils are described in Table 3 . The highest level of phytosterol contents was found in Tea camellia 
Table 2: Tocopherol $(\mathrm{T})$ contents in plant seed oils $(\mathrm{mg} / 100 \mathrm{~g})$

\begin{tabular}{lcccrc}
\hline Seed oils & $\boldsymbol{\alpha}-\mathbf{T}$ & $\boldsymbol{\beta}-\mathbf{T}$ & $\boldsymbol{\gamma}-\mathbf{T}$ & $\boldsymbol{\delta}$-T & \multicolumn{1}{c}{ Total-T } \\
\hline Camphor tree & $51.43 \pm 0.81^{\mathrm{c} 1)}$ & $2.10 \pm 0.02^{\mathrm{d}}$ & $3.10 \pm 0.04^{\mathrm{e}}$ & $1.30 \pm 0.05^{\mathrm{d}}$ & $57.91 \pm 1.22^{\mathrm{e}}$ \\
Australian laurel & $473.65 \pm 0.20^{\mathrm{a}}$ & $95.77 \pm 0.05^{\mathrm{a}}$ & $156.30 \pm 3.51^{\mathrm{b}}$ & $12.62 \pm 0.54^{\mathrm{a}}$ & $738.35 \pm 4.30^{\mathrm{a}}$ \\
Chinese flowering-quince & $61.42 \pm 0.85^{\mathrm{b}}$ & $1.09 \pm 0.01^{\mathrm{d}}$ & $1.10 \pm 0.01^{\mathrm{e}}$ & $1.08 \pm 0.00^{\mathrm{d}}$ & $64.72 \pm 0.85^{\mathrm{d}}$ \\
Fragrant citrus & $15.47 \pm 0.30^{\mathrm{g}}$ & $1.10 \pm 0.01^{\mathrm{d}}$ & $1.06 \pm 0.01^{\mathrm{e}}$ & $1.06 \pm 0.01^{\mathrm{d}}$ & $18.77 \pm 0.30^{\mathrm{g}}$ \\
Japanese mallotus & $27.98 \pm 0.48^{\mathrm{e}}$ & $1.08 \pm 0.01^{\mathrm{d}}$ & $295.36 \pm 0.44^{\mathrm{a}}$ & $9.46 \pm 0.07^{\mathrm{b}}$ & $333.90 \pm 1.00^{\mathrm{b}}$ \\
Tea camellia & $36.20 \pm 0.85^{\mathrm{d}}$ & $1.10 \pm 0.01^{\mathrm{d}}$ & $1.07 \pm 0.01^{\mathrm{e}}$ & $1.10 \pm 0.00^{\mathrm{d}}$ & $39.50 \pm 0.85^{\mathrm{f}}$ \\
Deodar & $17.83 \pm 0.17^{\mathrm{g}}$ & $8.25 \pm 0.20^{\mathrm{c}}$ & $36.60 \pm 0.37^{\mathrm{d}}$ & $5.04 \pm 1.13^{\mathrm{c}}$ & $67.73 \pm 0.80^{\mathrm{d}}$ \\
Naked-anther ternstroemia & $38.21 \pm 0.46^{\mathrm{d}}$ & $15.27 \pm 0.53^{\mathrm{b}}$ & $3.27 \pm 0.34^{\mathrm{e}}$ & $1.09 \pm 0.01^{\mathrm{d}}$ & $57.85 \pm 1.33^{\mathrm{e}}$ \\
Korean red pine & $21.51 \pm 0.02^{\mathrm{f}}$ & $1.07 \pm 0.01^{\mathrm{d}}$ & $67.24 \pm 0.70^{\mathrm{c}}$ & $1.92 \pm 0.01^{\mathrm{d}}$ & $91.77 \pm 0.69^{\mathrm{c}}$ \\
Large-leaflet prickly-ash & $1.52 \pm 0.11^{\mathrm{h}}$ & $1.06 \pm 0.01^{\mathrm{d}}$ & $1.05 \pm 0.01^{\mathrm{e}}$ & $1.10 \pm 0.01^{\mathrm{d}}$ & $4.82 \pm 0.11^{\mathrm{h}}$ \\
\hline
\end{tabular}

${ }^{1)}$ Means with different letters $(\mathrm{a}-\mathrm{h})$ within a column are significantly different $(P<0.05)$.

Table 3: Phytosterol contents in plant seed oils ( $\mathrm{mg} / 100 \mathrm{~g})$

\begin{tabular}{lccccc}
\hline Seed oils & Campesterol & Stigmasterol & $\beta$-Sitosterol & $\Delta^{5}$-Avenasterol & Total \\
\hline Camphor tree & $42.43 \pm 5.71^{\mathrm{b} 1)}$ & $227.73 \pm 0.19^{\mathrm{a}}$ & $19.74 \pm 3.58^{\mathrm{e}}$ & $29.71 \pm 0.34^{\mathrm{c}}$ & $319.61 \pm 9.44^{\mathrm{c}}$ \\
Australian laurel & $6.41 \pm 0.94^{\mathrm{g}}$ & $122.66 \pm 1.46^{\mathrm{c}}$ & $69.22 \pm 6.31^{\mathrm{d}}$ & $90.81 \pm 9.71^{\mathrm{b}}$ & $289.10 \pm 18.42^{\mathrm{d}}$ \\
Chinese flowering-quince & $4.32 \pm 0.09^{\mathrm{g}}$ & $113.34 \pm 4.07^{\mathrm{c}}$ & $10.32 \pm 0.66^{\mathrm{f}}$ & $5.46 \pm 0.27^{\mathrm{e}}$ & $133.44 \pm 5.09^{\mathrm{f}}$ \\
Fragrant citrus & $41.62 \pm 1.11^{\mathrm{b}}$ & $165.29 \pm 5.63^{\mathrm{b}}$ & $6.58 \pm 0.16^{\mathrm{g}}$ & $0.01 \pm 0.00 f$ & $213.50 \pm 6.90^{\mathrm{e}}$ \\
Japanese mallotus & $18.77 \pm 2.97^{\mathrm{e}}$ & $61.60 \pm 9.06^{\mathrm{f}}$ & $122.86 \pm 18.99^{\mathrm{c}}$ & $29.37 \pm 4.13^{\mathrm{c}}$ & $232.59 \pm 35.15^{\mathrm{e}}$ \\
Tea camellia & $10.82 \pm 0.88^{\mathrm{f}}$ & $77.19 \pm 3.90^{\mathrm{e}}$ & $124.71 \pm 11.60^{\mathrm{c}}$ & $190.87 \pm 13.51^{\mathrm{a}}$ & $403.59 \pm 29.89^{\mathrm{a}}$ \\
Deodar & $37.83 \pm 0.95^{\mathrm{c}}$ & $94.39 \pm 2.11^{\mathrm{d}}$ & $17.00 \pm 0.37^{\mathrm{e}}$ & $3.93 \pm 0.13^{\mathrm{e}}$ & $153.16 \pm 3.55^{\mathrm{f}}$ \\
Naked-anther ternstroemia & $30.12 \pm 1.46^{\mathrm{d}}$ & $72.24 \pm 3.22 \mathrm{f}^{\mathrm{e}}$ & $7.64 \pm 0.13 \mathrm{~g}$ & $102.05 \pm 5.18^{\mathrm{b}}$ & $212.05 \pm 9.99^{\mathrm{c}}$ \\
Korean red pine & $49.02 \pm 1.67^{\mathrm{a}}$ & $3.51 \pm 0.01^{\mathrm{h}}$ & $202.50 \pm 7.35^{\mathrm{a}}$ & $99.46 \pm 3.56^{\mathrm{b}}$ & $352.74 \pm 10.10^{\mathrm{b}}$ \\
Large-leaflet prickly-ash & $31.51 \pm 0.48^{\mathrm{d}}$ & $17.37 \pm 0.21^{\mathrm{g}}$ & $140.52 \pm 2.45^{\mathrm{b}}$ & $15.17 \pm 0.26^{\mathrm{d}}$ & $204.57 \pm 3.39^{\mathrm{e}}$ \\
\hline
\end{tabular}

1) Means with different letters $(a-h)$ within a column are significantly different $(P<0.05)$.

$(403.59 \pm 29.89 \mathrm{mg} / 100 \mathrm{~g})$ while lowest in Chinese flowering-quince $(133.44 \pm 5.09 \mathrm{mg} / 100 \mathrm{~g})$. Of phytosterols, campesterol existed in the highest level in Korean red pine, $(49.02 \pm 1.67 \mathrm{mg} / 100 \mathrm{~g})$, stigmasterol in Camphor tree $(227.73 \pm 0.19 \mathrm{mg} / 100 \mathrm{~g}), \beta$-sitosterol in Korean red pine $(202.50 \pm 7.35 \mathrm{mg} / 100 \mathrm{~g})$, and $\Delta^{5}$-avenasterol in Tea camellia $(190.87 \pm 13.51 \mathrm{mg} / 100 \mathrm{~g})$. Phytosterol is a plant derived-steroid that shares similar structures and functions with cholesterol, existing in two types, sterols and stanols, depending on the degree of saturation (Ostlund, 2002). Humans are unable to synthesize phytosterol in the body and therefore should be obtained from their diet (Moreau et al., 2002). Among phytosterols, $\beta$-sitosterol is most abundantly available in the human diet $(65 \%)$, followed by campesterol (30\%) and stigmasterol (3\%) (Ostlund, 2002). Phytosterol presents rich in unpurified vegetable oils, olives, nuts, and legumes (Valsta et al., 2007). Literature have highlighted various health effects of phytosterol; decreasing serum LDL cholesterol levels (Moreau et al., 2002), lowering inflammatory activity (Awad et al., 2004), and aiding cancer cell death (Awad et al., 2003). Given the health benefits and its non-synthesis and low absorption in the human body, the plant seed oils may be a sound option as a great source of phytosterol intake.

\section{Acid values, Peroxide values, and $\boldsymbol{p}$-anisidine values}

Acid values, peroxide values, and $p$-anisidine values determined in 10 plant seed oils are shown in Table 4.
Acid values were identified in the highest level in Japanese mallotus, $52.3 \pm 0.60 \mathrm{mg} \mathrm{KOH} / \mathrm{g}$, and in the lowest level in Tea camellia, $0.81 \pm 0.04 \mathrm{mg} \mathrm{KOH} / \mathrm{g}$. Acid values indicate the amount of potassium hydroxide consumed by neutralizing free fatty acids in oils (1g). Higher acid values mean higher contents of free fatty acids, indicating a degraded quality of oils (Jiang et al., 2019). Such high acid value in Japanese mallotus may come from either acidification or free fatty acids present beforehand (Kim et al., 2018). In case of peroxide values, Large-leaflet prickly-ash showed the highest level, $213.88 \pm 6.97 \mathrm{meq} / \mathrm{kg}$, while Chinese flowering-quince the lowest, $4.95 \pm 0.11$ $\mathrm{meq} / \mathrm{kg}$. Peroxide values measure the concentration of hydrogen peroxide, the primary oxidation product, which is an important estimate of early phase oxidation (Kaleem et al., 2015). Peroxide value is an appropriate measure to assess the time-dependent quality of oil-containing foods, meaning that a drastic increase of peroxide value indicates deteriorated oils after the early oxidation (Asakawa and Matsushita, 1980). For $p$-anisidine values, Large-leaflet prickly-ash marked the highest value, $62.59 \pm 1.67$, and Deodar the lowest value, $3.53 \pm 0.39$. $p$-anisidine values measure the amount of secondary oxidation products, mainly the carbonyl compounds such as aldehydes and ketones. Higher $p$-anisidine values mean higher levels of carbonyl compounds generated by lipid oxidation (Tompkins and Perkins, 1999; Naz et al., 2004). Rancidity, which is determined by acid values, peroxide values, and 
$p$-anisidine values, is a critical estimate of off-flavors and undesirable sensory characteristics in lipid-containing foods, probably influencing overall sensory preferences and acceptability (Kaleem et al., 2015). It is therefore important to control the extent of lipid oxidation in order to utilize the plant seed oils as potential food sources.

\section{Color scale and browning intensity}

Color scale and browning intensity of 10 plant seed oils are described in Table 5 . In terms of color scale, $L^{*}$ value, indicating brightness, showed highest in Deodar $(45.47 \pm 0.10)$ with no significant difference from Camphor tree, Chinese flowering-quince, Fragrant citrus, Japanese mallotus, and Tea camellia. $a^{*}$ value, reflecting redness, had highest in Naked-anther ternstroemia (13.77 \pm 0.01$)$. Some samples including Chinese flowering-quince, Tea camellia, and Deodar had negative $a^{*}$ values, which indicates a complementary color of red, greenness (Kim et al., 2018). In case of $b^{*}$ value, exhibiting yellowness, Tea camellia had the highest value $(13.31 \pm 0.08)$. Korean red pine and Largeleaflet prickly-ash had negative $b^{*}$ values, which indicate an increased blueness (Sun, 2012). For browning intensity, both Australian laurel and Naked-anther ternstroemia showed the highest values $(3.00<)$. Browning intensity is determined by browning from lipid oxidation and the brown pigment that the sample possesses (Kim et al., 2018). Not only loss of nutritional values, color changes in foods are closely linked to sensory quality such as off flavors development, texture changes, and consumer preference and acceptability degradation (Lawless and Heymann, 1999). In this regards, assessing color values and browning intensity is of significance in widening the application of the plant seed oils to food substances.

\section{Oxidative stability}

Oxidative stability of 10 plant seed oils expressed as induction times are shown in Table 6. In the early phase of lipid oxidation, oxygen uptake is maintained constant but rapidly increased after reaching the maximum uptake before acidification, which refers to an oxidation induction period. Afterwards, the formation of oxidation products is promptly increased, leading to oxidative rancidity due to various physicochemical changes in the lipid. Oxygen uptake is mainly influenced by degree of unsaturation, storage temperature, and the presence of antioxidants and oxidizing agents (Damodaran et al., 2008; Lee et al., 2009). In this study, 10 plant seed oils showed a varied range of induction periods, among which Chinese flowering-quince showed the longest induction period $(3.72 \pm 0.28 \mathrm{hr})$ whereas Large-leaflet prickly-ash the shortest $(0.02 \pm 0.01 \mathrm{hr})$. Along with the induction times, the proportion of polyunsaturated fatty acids in fatty acid profiles is also a critical indicator of determining oxidative stability. In general, a higher degree of polyunsaturation

Table 4: Acid values, peroxide values, and $p$-anisidine values in plant seed oils

\begin{tabular}{lccc}
\hline Seed oils & Acid value $(\mathbf{m g ~ K O H} / \mathrm{g})$ & Peroxide value $(\mathrm{meq} / \mathrm{kg})$ & $p$-Anisidine value \\
\hline Camphor tree & $10.08 \pm 0.77^{\mathrm{c} 1)}$ & $53.07 \pm 4.23^{\mathrm{b}}$ & $28.31 \pm 1.02^{\mathrm{c}}$ \\
Australian laurel & $10.47 \pm 0.76^{\mathrm{c}}$ & $29.53 \pm 0.20^{\mathrm{c}}$ & $51.97 \pm 3.80^{\mathrm{b}}$ \\
Chinese flowering-quince & $3.95 \pm 0.00^{\mathrm{d}}$ & $4.95 \pm 0.11^{\mathrm{e}}$ & $14.73 \pm 1.00^{\mathrm{e}}$ \\
Fragrant citrus & $1.85 \pm 0.21^{\mathrm{e}}$ & $24.74 \pm 1.00^{\mathrm{c}}$ & $15.48 \pm 0.66^{\mathrm{e}}$ \\
Japanese mallotus & $52.3 \pm 0.60^{\mathrm{a}}$ & $27.08 \pm 0.83^{\mathrm{c}}$ & $19.26 \pm 3.24^{\mathrm{d}}$ \\
Tea camellia & $0.81 \pm 0.04^{\mathrm{e}}$ & $14.05 \pm 0.16^{\mathrm{d}}$ & $5.86 \pm 0.68^{\dagger}$ \\
Deodar & $11.17 \pm 3.86^{\mathrm{c}}$ & $5.30 \pm 0.49^{\mathrm{e}}$ & $3.53 \pm 0.39^{\mathrm{g}}$ \\
Naked-anther ternstroemia & $3.51 \pm 0.30^{\mathrm{d}}$ & $14.18 \pm 0.14^{\mathrm{d}}$ & $20.61 \pm 3.34^{\mathrm{d}}$ \\
Korean red pine & $4.52 \pm 0.37^{\mathrm{d}}$ & $7.32 \pm 0.16^{\mathrm{e}}$ & $22.29 \pm 0.47^{\mathrm{d}}$ \\
Large-leaflet prickly-ash & $35.25 \pm 0.30^{\mathrm{b}}$ & $213.88 \pm 6.97^{\mathrm{a}}$ & $62.59 \pm 1.67^{\mathrm{a}}$ \\
\hline
\end{tabular}

${ }^{1)}$ Means with different letters $(\mathrm{a}-\mathrm{h})$ within a column are significantly different $(P<0.05)$.

Table 5: Colorimetry values and browning intensities in plant seed oils

\begin{tabular}{|c|c|c|c|c|}
\hline \multirow[t]{2}{*}{ Seed oils } & \multicolumn{3}{|c|}{ Colorimetry values } & \multirow[t]{2}{*}{ Browning intensity } \\
\hline & Lightness $\left(L^{*}\right)$ & Redness $\left(a^{*}\right)$ & Yellowness $\left(b^{\star}\right)$ & \\
\hline Camphor tree & $42.47 \pm 0.10^{\mathrm{a} 1)}$ & $0.11 \pm 0.02^{\mathrm{e}}$ & $6.28 \pm 0.04^{b}$ & $2.68 \pm 0.08^{a}$ \\
\hline Australian laurel & $33.74 \pm 0.03^{b}$ & $9.85 \pm 0.09^{b}$ & $0.46 \pm 0.08^{f}$ & $3.00<$ \\
\hline Chinese flowering-quince & $44.06 \pm 0.02^{\mathrm{a}}$ & $-0.17 \pm 0.05^{f}$ & $2.94 \pm 0.04^{d}$ & $0.83 \pm 0.01^{c}$ \\
\hline Fragrant citrus & $44.89 \pm 0.01^{\mathrm{a}}$ & $0.17 \pm 0.06^{e}$ & $1.20 \pm 0.02^{\mathrm{e}}$ & $0.35 \pm 0.02^{\mathrm{e}}$ \\
\hline Japanese mallotus & $44.44 \pm 0.69^{a}$ & $0.73 \pm 0.10^{d}$ & $0.17 \pm 0.05^{g}$ & $0.53 \pm 0.04^{d}$ \\
\hline Tea camellia & $43.94 \pm 0.02^{\mathrm{a}}$ & $-2.64 \pm 0.07^{h}$ & $13.31 \pm 0.08^{a}$ & $1.90 \pm 0.03^{b}$ \\
\hline Deodar & $45.47 \pm 0.10^{\mathrm{a}}$ & $-0.88 \pm 0.02^{g}$ & $4.48 \pm 0.12^{\mathrm{c}}$ & $0.79 \pm 0.05^{c}$ \\
\hline Naked-anther ternstroemia & $34.92 \pm 0.01^{b}$ & $13.77 \pm 0.01^{\mathrm{a}}$ & $3.08 \pm 0.01^{\mathrm{cd}}$ & $3.00<$ \\
\hline Korean red pine & $31.72 \pm 0.01^{c}$ & $1.31 \pm 0.21^{c}$ & $-2.65 \pm 0.09^{f}$ & $0.78 \pm 0.05^{c}$ \\
\hline Large-leaflet prickly-ash & $32.25 \pm 0.01 b^{c}$ & $1.44 \pm 0.27^{c}$ & $-3.27 \pm 0.10^{f}$ & $0.42 \pm 0.01^{d}$ \\
\hline
\end{tabular}

${ }^{1}$ Means with different letters $(\mathrm{a}-\mathrm{h})$ within a column are significantly different $(P<0.05)$. 
Table 6: Oxidative induction times in plant seed oils

\begin{tabular}{lc}
\hline Seed oils & Induction time (hr) \\
\hline Camphor tree & $0.04 \pm 0.03^{\mathrm{f} 1)}$ \\
Australian laurel & $0.36 \pm 0.00^{\mathrm{e}}$ \\
Chinese flowering-quince & $3.72 \pm 0.28^{\mathrm{a}}$ \\
Fragrant citrus & $1.16 \pm 0.09^{\mathrm{d}}$ \\
Japanese mallotus & $0.29 \pm 0.18^{\mathrm{e}}$ \\
Tea camellia & $0.04 \pm 0.03^{\dagger}$ \\
Deodar & $0.20 \pm 0.11^{\mathrm{e}}$ \\
Naked-anther ternstroemia & $2.77 \pm 0.30^{\mathrm{b}}$ \\
Korean red pine & $2.31 \pm 0.01^{\mathrm{bc}}$ \\
Large-leaflet prickly-ash & $0.02 \pm 0.01^{\dagger}$ \\
\hline${ }^{1}$ Means with different letters (a-h) within a column are significantly
\end{tabular}

different $(P<0.05)$.

is prone to lipid oxidation, resulting in low oxidative stability. In this study, however, Chinese flowering-quince had relatively higher proportion of polyunsaturated fatty acids (32\%) while showed the highest oxidative stability. Similarly, Large-leaflet prickly-ash possessed the lowest proportion of polyunsaturated fatty acids $(8 \%)$ yet showed the lowest oxidative stability. Other chemical measures of Large-leaflet prickly-ash examined previously showed congruent results with the induction period; the second highest acid value $(35.25 \pm 0.30 \mathrm{mg} \mathrm{KOH} / \mathrm{g})$, the highest peroxide value $(213.88 \pm 6.97 \mathrm{meq} / \mathrm{kg})$, and the highest $\mathrm{p}$-anisidine value (62.59 \pm 1.67$)$. Such discrepancy is presumably due to the fact that oxidative stability is governed by not only a degree of unsaturation but by the presence of inherent volatile compounds, free fatty acids, phospholipids, and other hydrophobic compounds in the lipids (Kim et al., 2017; Kim et al., 2018). Martín-Polvillo and others (2004) reported that oxidation of sunflower oils was accelerated mainly by the contents of triglyceride monomers generated during the initial oxidation phase, regardless of unsaturation extent. Another study by Mancebo-Campos (2007) investigated oxidative stability of virgin olive oils and resulted in various induction periods (65-140 hr) within the sample. Therefore, more in-depth research seems necessary to investigate how degrees of unsaturation and the inherent factors of oxidation influence oxidative stability in an accurate manner.

\section{CONCLUSION}

To establish baseline data of plant seed oils obtained from forest resources to utilize as foods and food ingredients and extending their applications, this study examined fatty acid compositions, antioxidative nutrient contents, and physicochemical characteristics of 10 plant seed oils derived from wild forest. In fatty acid compositions, oleic acid showed the highest proportion across all the seed oils except for Chinese flowering-quince and Korean red pine. Overall, all seed oils had more than $50 \%$ of unsaturated fatty acids.
While the seed oils showed a broad range of the antioxidants, Australian laurel and Tea camellia had the highest level of tocopherol and phytosterol, respectively. In case of chemical measures, acid value, peroxide value, and $p$-anisidine value resulted in varied ranges and these parameters need to be appropriately controlled to prevent oil rancidity and quality deterioration. Browning intensity and color scale were also examined, which can be a good parameter of sensory quality. Oxidation induction time was estimated as a measure of oxidative stability and Chinese flowering-quince was found to have the highest oxidative stability. The results of this study offered informative baseline data regarding 10 plant seed oils from forest resources and showed the potential of these oils as food sources and ingredients based on their positive nutrient and physicochemical features.

\section{ACKNOWLEDGEMENT}

This study was funded by the Basic Science Research Program, through the National Research Foundation of Korea (NRF) funded by the Ministry of Education (NRF2018R1D1A1B07045431).

\section{Author contributions}

Overall data collection and writing a draft, Jookyeong Lee and Seong Jun Hong; nutritional component analyses and data collection, Joon Hyung Park and Jin-Ju Cho; analyses of oxidative stability analyses and other chemical measures and data collection, Da-Som Kim and Kyoung-Tae Lee; providing critical comments on draft and supervision; Oh-Kyu Lee; and overall project design, organization, and supervision, Eui-Cheol Shin.

\section{REFERENCES}

Aggarwal, V., D. Kashyap, S. Katrin, H. S. Tuli, J. Aklank, A. Chaudhary, V. K. Garg, G. Sethi and M. B. Yerer. 2019. Molecular mechanisms of action of tocotrienols in cancer: Recent trends and advancements. Int. J. Mol. Sci. 20(3): 656.

Asakawa, T. and S. Matsushita. 1980. Acolorimetric microdetermination of peroxide values utilizing aluminum chloride as catalyst. Lipids. 15(11): 965-967.

Awad, A. B., R. Roy and C. S. Fink. 2003. $\beta$-sitosterol, a plant sterol, induces apoptosis and activates key caspases in MDA-MB-231 human breast cancer cells. Oncol. Rep. 10(2): 497-500.

Awad, A. B., J. Toczek and C. S. Fink. 2004. Phytosterols decrease prostaglandin release in cultured $\mathrm{P} 388 \mathrm{D}_{1} / \mathrm{MAB}$ macrophages. Prostaglandins Leukot. Essent. Fatty Acids. 70(6): 511-520.

Bowen, K. J., P. M. Kris-Etherton, S. G. West, J. A. Fleming, P. W. Connelly, B. Lamarche, P. Couture, David. J. Jenkins, C. G. Taylor, P. Zahradka, S. S. Hammad, J. Sihag, X. Chen, V. Guay, J. Maltais-Giguère, D. Perera, A. Wilson, S. C. S. Juan, J. Rempel and P. J. H. Jones. 2019. Diets enriched with conventional or high-oleic acid canola oils lower atherogenic lipids and lipoproteins compared to a diet with a western fatty acid profile in adults with central adiposity. J. Nutr. 149(3): $471-478$ 
Burge. G. C. and S. A, Wootton. 2002. Conversion of $\alpha$-linolenic acid to eicosapentaenoic, docosapentaenoic and docosahexaenoic acids in young women. Br. J. Nutr. 88(4): 411-420.

Burdge, G. 2004. a-Linolenic acid metabolism in men and women: Nutritional and biological implications. Curr. Opin. Clin. Nutr. Metab. Care. 7(2): 137-144.

Cervantes, B. and L. M. Ulatowski. 2017. Vitamin E and Alzheimer's disease is it time for personalized medicine? Antioxidants. 6(3):-45.

Currie, E., A. Schulze, R. Zechner, T. C. Walther and R. V. Jr. Farese. 2013. Cellular fatty acid metabolism and cancer. Cell Metab. 18(2):153-161.

Damodaran, S., K. L. Parkin and O. R. Fennema. 2008. Fennema's food chemistry. $4^{\text {th }}$ ed. CRC Press, Taylor and Francis Group. Boca Raton, Florida, pp. 186-208.

Eitenmiller, R. R. and J. Lee. 2004. Vitamin E: Food Chemistry, Composition, and Analysis, Marcel Dekker Inc., New York, USA.

Ghosh, S., K. Datta and S. K. Datta. 2019. 7-Rice vitamins. Rice Chem. Tech. 195-220.

Grando-Casas, M. and D. Mauricio. 2019. Bioactive food as dietary interventions for diabetes. In: Oleic Acid in the Diet and What it Does: Implications for Diabetes and its Complications. $2^{\text {nd }}$ ed., Ch. 14. Elsevier Inc., Philadelphia, PA, pp. 211-229.

Innes, J. K. and P. C. Calder. 2018. Omega-6 fatty acids and inflammation. Prostaglandins Leukot. Essent. Fatty Acids. 132: 41-48.

Jiang, X., S. Li, G. Xiang, Q. Li, L. Fan, L. He and K. Gu. 2019. Determination of the acid values of edible oils via FTIR spectroscopy based on the O-H stretching band. Food Chem. 212: 585-589.

Jump, D. B., C. M. Depner and S. Tripathy. 2012. Omega-3 fatty acid supplementation and cardiovascular disease. J. Lipid Res. 53(12): 2525-2545.

Kaleem, A., S. Aziz, M. Iqtedar, R. Abdullah, M. Aftab, F. Rashid, F. R. Shakoori and S. Naz. 2015. Investigating changes and effect of peroxide values in cooking oils subject to light and heat. Fuuast J. Biol. 5(2): 191-196.

Khan, H. A., W. Akram, S. Lee, T. Ahmad, K. Maqsood, H. A. Khan, M. W. Nazir and M. F. Javaid. 2019. Toxic potential of some indigenous plant oils against the rice weevil, Sitophilus oryzae (Linnaeus). Entomol. Res. 49: 136-140.

Kim, D. S., H. S. Kim, K. T. Lee, D. L. Hong, S. R. Cho, J. H. Pan, Y. B. Park, Y. B. Lee, J. K. Kim and E. C. Shin. 2018. Chemical characterization and oxidative stability of medium and longchain fatty acid profiles in tree-borne seed oils. J. Anal. Methods Chem. 2018: 2178684.

Kim, H. S., D. S. Kim, J. Lee, S. J. Hong, J. J. Cho, S. Woo and E. C. Shin. 2018. Characterization of edible oil containing Wasabi during frying process. J. Korean Soc. Food Sci. Nutr. 47(11): 1191-1199.

Kim, M. S., J. H. Park, H. J. Lim, D. S. Kim, H. S. Kim, K. T. Lee, Y. B. Park and E. C. Shin. 2017. Nutritional components and physicochemical properties of lipids extracted from forest resources. J. Korean Soc. Food Sci. Nutr. 46: 529-536.

Lawless, H. T. and H. Heymann, H. 1999. Sensory evaluation of food: Principles and practices. In: R. Bloom (Ed.), Springer Science and Business Media, Aspen Publishers, New York.

Lee, K. W., H. J. Lee, H. Y. Cho and Y. J. Kim. 2005. Role of the conjugated linoleic acid in the prevention of cancer. Crit. Rev. Food Sci. Nutr. 45(2):135-44.

Lee, S. Y., H. J. Jeong, Y. E. Lee, M. R. Kim, M. R. Kim and H. N. Song. 2009. Food chemistry. Powerbook, Mapo, Seoul, Republic of Korea, p. 111-130.

Lenighan, Y. M., B. A. McNulty and H. M. Roche. 2019. Dietary fat composition: Replacement of saturated fatty acids with PUFA as a public health strategy, with an emphasis on a-linolenic acid. Proc. Nutr. Soc. 78(2): 234-245.

Mancebo-Campos, V., M. D. Salvador and G. Fregapane. 2007. Comparative study of virgin olive oil behavior under rancimat accelerated oxidation conditions and long-term room temperature storage. J. Agric. Food Chem. 55(20). 8231-8236.

Martín-Polvillo, M., G. Márquez-Ruiz and M. Dobarganes. 2004. Oxidative stability of sunflower oils differing in unsaturation degree during long-term storage at RT. J. Am. Oil Chem. Soc. 81: 577-583.

Marventano, S., P. Kolacz, S. Castellano, F. Galvano, S. Buscemi, A. Mistretta and G. Grosso. 2015. A review of recent evidence in human studies of n-3 and n-6 PUFA intake on cardiovascular disease, cancer, and depressive disorders: Does the ratio really matter? Int. J. Food Sci. Nutr. 66(6): 611-622.

Moreau, R. A., B. D. Whitaker and K. B. Hicks. 2002. Phytosterols, phytostanols, and their conjugates in foods: Structural diversity, quantitative analysis, and health-promoting uses. Prog. Lipid Res. 41(6): 457-500.

Nakamura, Y. K., N. Flintoff-Dye and S. T. Omaye. 2008. Conjugated linoleic acid modulation of risk factors associated with atherosclerosis. Nutr. Metab. 5(22): 22.

Naz, S., H. Sheikh, R. Siddiqi and S. A. Sayeed. 2004. Oxidative stability of olive, corn and soybean oil under different conditions. Food Chem. 88: 253-259.

Nelson, G. J. 1992. Dietary fatty acids and lipid metabolism. In: C. K. Chow, (Ed.), Fatty acids in Foods and Their Health Implications. Marcel Dekker Inc., New York, USA.

Noh, S. and S. H. Yoon. 2012. Stereospecific positional distribution of fatty acids of Camellia (Camellia japonica L.) seed oil. J. Food Sci. 77: C1055-C1057.

Ostlund, R. E. 2002. Phytosterols in human nutrition. Annu. Rev. Nutr. 22: $533-549$.

Pham, D. Q. and R. Plakogiannis. 2005. Vitamin E supplementation in cardiovascular disease and cancer prevention: Part 1. Ann. Pharmacother. 39(11): 1870-1878.

Prato, E. and F. Biandolino. 2012. Total lipid content and fatty acid composition of commercially important fish species from the Mediterranean, Mar Grande Sea. Food Chem. 131: 1233-1239.

Shin, E. C., Y. Z. Huang, R. B. Pegg, R. D. Phillips and R. R. Eitenmiller. 2009. Commercial runner peanut cultivars in the United States: Tocopherol composition. J. Agric. Food Chem. 57(21): 1028910295.

Shin, E. C., R. B. Pegg, R. D. Phillips and R. R. Eitenmiller. 2010. Commercial peanut (Arachis hypogaea L.) cultivars in the United States: Phytosterol composition. J. Agric. Food Chem. 58: 9137-9146.

Sozen, E., T. Demirel and N. K. Ozer. 2019. Vitamin E: Regulatory Role in the Cardiovascular System. International Union of Biochemistry and Molecular Biology, Spain.

Sun, D. W. 2012. Thermal Food Processing: New Technologies and Quality Issues. CRC Press, Taylor and Francis Group, Boca Raton, Florida.

Tompkins, C. and E. G. Perkins. 1999. The evaluation of frying oils with the $p$-Anisidine value. J. Am. Oil Chem. Soc. 76(8): 945-947.

Valsta, L. M., A. Lemström, M. L. Ovaskainen, A. M. Lampi, J. Toivo, T. Korhonen and V. Piironen. 2007. Estimation of plant sterol and cholesterol intake in Finland: Quality of new values and their effect on intake. Br. J. Nutr. 92(4): 671-678.

Wayne, L. A., D. J. Gachotte and T. A. Walsh. 2018. Transgenic and genome editing approaches for modifying plant oils. Transgenic Plants. 1864: 367-394. 